\title{
Article \\ Growth Performance, Nutrient Digestibility, Blood Profiles, and Gut Integrity of Growing Pigs Fed Pickled Fish Residue with Decreased Salt Content
}

\author{
Waewaree Boontiam $^{1, * \mathbb{C}}$, Sumetee Kitipongpysan ${ }^{2}$, Chalong Wachirapakorn ${ }^{1}{ }^{\mathbb{D}}$, Jinsu Hong ${ }^{3} \mathbb{D}$, \\ Somsamorn Gawborisut ${ }^{4}$ and Amporn Saeeaw ${ }^{5}$ \\ 1 Division of Animal Science, Faculty of Agriculture, Khon Kaen University, Khon Kaen 40002, Thailand; \\ chal_wch@kku.ac.th \\ 2 Division of Agriculture, Faculty of Agriculture and Life Sciences, Chandrakasem Rajabhat University, \\ Bangkok 10900, Thailand; sumetee.k@chandra.ac.th \\ 3 Department of Animal Science, South Dakota State University, Brookings, SD 57007, USA; \\ Jinsu.hong@sdstate.edu \\ 4 Fish Processing Laboratory, Department of Fisheries, Faculty of Agriculture, \\ Khon Kaen University, Khon Kaen 40002, Thailand; somgaw@kku.ac.th \\ 5 Division of Food Technology, Faculty of Technology, Khon Kaen University, Khon Kaen 40002, Thailand; \\ sampor@kku.ac.th \\ * Correspondence: waewbo@kku.ac.th; Tel.: +66-64-212-4717
}

check for

updates

Citation: Boontiam, W.;

Kitipongpysan, S.; Wachirapakorn, C.;

Hong, J.; Gawborisut, S.; Saeeaw, A.

Growth Performance, Nutrient

Digestibility, Blood Profiles, and Gut

Integrity of Growing Pigs Fed

Pickled Fish Residue with Decreased

Salt Content. Fermentation 2022, 8, 3 .

https://doi.org/10.3390/

fermentation 8010003

Academic Editor: Hiroshi Kitagaki

Received: 28 November 2021

Accepted: 22 December 2021

Published: 24 December 2021

Publisher's Note: MDPI stays neutral with regard to jurisdictional claims in published maps and institutional affiliations.

Copyright: (C) 2021 by the authors. Licensee MDPI, Basel, Switzerland. This article is an open access article distributed under the terms and conditions of the Creative Commons Attribution (CC BY) license (https:// creativecommons.org/licenses/by/ $4.0 /)$.

\begin{abstract}
This study investigated the growth performance, nutrient digestibility, blood profiles and gut integrity of growing pigs, in response to an increase in pickled freshwater fish residue (PFR) intake following a decrease in salt content. Ninety-six crossbred growing pigs [(Landrace $\times$ Large White $) \times$ Duroc] with a body weight of $23.65 \pm 0.24 \mathrm{~kg}$ were randomly assigned to one of four treatments ( 6 pens / treatment, 4 pigs/pen) in a randomized complete block design. The treatments included: a corn-soybean meal based diet without PFR inclusion (CON) or with PFR addition at 5 (PFR5), 10 (PFR10), and 15\% (PFR15), respectively. Desalting via soaking and stirring caused a positive reduction in the salt present on the surface of PFR. Over the 42-day feeding period, an increased level of PFR quadratically increased gain:feed ratio such that gain:feed ratio for PFR10 was greater than that for CON $(p<0.05)$. Pigs fed PFR10 had greater crude protein digestibility, and lower aspartate aminotransferase and crypt depth than those fed the CON diet $(p<0.05)$. The linear improvements in crude protein and ether extract digestibility, duodenal villus height, and villus:crypt ratio were observed as the PFR content increased $(p<0.05)$. However, there were no significant effects on average daily feed intake, dry matter and ash digestibility, blood metabolites (total Ca, P, creatinine, and alkaline phosphatase). Altogether, up to $10 \%$ PFR can be included in corn-soybean meal diet without impairing protein digestibility and hepatic enzyme alteration. In fact, administering PFR with lower salt content to growing pigs ultimately promotes their growth performance and gut integrity.
\end{abstract}

Keywords: pickled fish residue; growth performance; nutrient digestibility; blood profiles; gut integrity; growing pigs

\section{Introduction}

Plara is well recognized as a traditional Thai seasoning and is highly favoured in Southeast Asian countries, particularly Cambodia, Laos, Vietnam, and Thailand. Plara is fabricated via the fermentation of various freshwater fish with rice bran or roasted rice flour and salt (up to $7-16 \%$ ) in an aerobic container for more than six months $[1,2]$. Currently, the pickled fish industry in Thailand is markedly growing, producing over 52,000 tonnes per year (worth approximately 34 million USD/year). Disposal products such as fish bones, scales, roasted rice flour, and mixtures of roasted rice flour, scales, bone, muscle, and salt residues_estimated to be 1500 tonnes annually_are dumped 
into landfills without treatment. This negatively affects the environment and human health. Ogata et al. [3] demonstrated that high salinity causes changes in the degradation of organic compounds, and the community of bacterial and archaeal compositions. To offset environmental pollution and disposal problems, the use of mixture pickled fish residue (PFR) can be possibly employed as an alternative feed ingredient for livestock. PFR contains remarkable amounts of lactic acid bacteria, Lactobacillus plantarum, L. Brevis, Pediococcus acidilactici, Enterococcus faecium, and E. faecalis, owing to their ability to tolerate highly concentrated salt solutions. Furthermore, the average contents of protein and fat are $17.22 \%$ and $6.11 \%$, respectively [1]. The addition of high concentrations of salt to the pickled fish process can enable the control of Clostridium perfringens contamination, whose content is lower than $100 \mathrm{cfu} / \mathrm{g}$ [4]. The recommended level of salt intake in a pig's diet should be less than $0.59 \%$ and should not impair its growth rate [5]. However, no reports on dietary PRF supplementation for monogastric animals are available. One relevant report revealed that the inclusion of $20 \%$ tilapia (Oreochromis niloticus) filleting waste meal in the diet of growing pigs significantly increased their body weight, average daily gain, and feed efficiency [6]. Regarding the nutritional characteristics of PRF, it can be utilized as a good alternative ingredient for monogastric animals. Therefore, we hypothesized that a further process to eliminate salt in PRF meal may provide adequate nutrients and proper feed characteristics to promote the growth performance and health status of growing pigs. To test this hypothesis, the nutrient composition, colour, and feed morphology of PFR were evaluated in the present study. Furthermore, the effect of dietary PFR inclusion on the growth performance, nutrient digestibility, blood profile, and intestinal morphology of growing pigs was determined.

\section{Materials and Methods}

\subsection{Ethical Statement}

The animal handling procedures were reviewed and approved by the Institutional Animal Care and Use Committee of Khon Kaen University (IACUC-KKU61/64, approved on 17 June 2020, Khon Kaen, Thailand).

\subsection{Preparation of Pickled Freshwater Fish Residue}

Fresh PFR was obtained from a fish manufacturer (Phetdam Food Co., Ltd., Kalasin, Thailand) as a single batch produced after six month of fermentation. The collected sample was soaked in tap water (1:1 ratio) for $30 \mathrm{~min}$, dehydrated, and placed in a stainless mixing tank. Tap water was then added to the sample in a 1:1 ratio, and the solution was constantly mixed at $43.88 \mathrm{rpm}$ for $30 \mathrm{~min}$ using a stirrer with a maximum capacity of $100 \mathrm{~kg}$. Thereafter, the sample was dried in an oven at $65^{\circ} \mathrm{C}$ for $48 \mathrm{~h}$ and subsequently ground into small $0.88 \mathrm{~mm}$-sized particles using a Wiley mill. The grinding PFR was divided into two proportions (500 g each) to determine the amount of moisture, ash, crude protein (CP), ether extract (EE), crude fibre, nitrogen-free extract, calcium, and phosphorus contents according to the standard protocol [7]. Gross energy was determined using a bomb calorimeter (Model 6400, Parr Instruments, Moline, IL, USA), whereas salt content was determined via silver nitrate titration. The colours of lightness $\left(L^{*}=89.2\right.$, black to white), redness ( $a^{*}=0.921$, red to green), and yellowness $\left(b^{*}=0.783\right.$, yellow to blue) were determined using a CR-410 Chroma Meter (Konica Minolta Sensing Inc., Osaka, Japan) at three surface areas. Another portion of sample was used to assess the feed morphological structure. Briefly, a dried specimen (approximately $1 \mathrm{~cm}^{2}$ ) of ground PFR was mounted, with the uppermost inner slides on aluminium stubs and coated with platinum using a vacuum coater (RMC-Eiko RE, Eiki Engineering Co., Ltd., Ibaraki,Japan). This was done for direct observation using a scanning electron microscope (S-800, Hitchi Ltd., Tokyo, Japan) at an accelerating voltage of $15 \mathrm{kV}$ and magnifications of $100 \times$ and $500 \times$. 


\subsection{Animals and Treatments}

Ninety-six crossbred growing pigs [(Landrace $\times$ Large White $) \times$ Duroc)]; average body weight (BW), $23.65 \pm 0.24 \mathrm{~kg}$ ) were assigned to four experimental treatments, based on their initial BW and sex, in a randomized complete block design. Each treatment had six replicates (pens, $1.92 \mathrm{~m} \times 2.3 \mathrm{~m}$, providing a stocking density of $1.10 \mathrm{~m}^{2} / \mathrm{pig}$ ) with four pigs per pen (two gilts and two barrows). The pens had solid flooring, and were equipped with a polyvinyl feeder and a nipple drinker to allow free access to fresh water and a mash diet during the 42-day feeding period, as per international guidelines [8]. Pigs were housed in a semi-controlled building, with temperature and relative humidity ranging from 28 to $32{ }^{\circ} \mathrm{C}$ and 60 to $65 \%$, respectively. Daily cleaning and hygiene procedures were performed to prevent disease and control the ammonia concentration. The following experimental diets were provided: CON, a corn-soybean diet without PFR or with PFR5, PFR10, and PFR15, which were supplemented with 5, 10, and 15\% of PFR, respectively. The diets were formulated to meet or exceed the nutrient requirements for growing pigs weighing 25 to $50 \mathrm{~kg}$, as recommended by the NRC [9]. The ingredients and nutrient compositions of the diet are listed in Table 1.

Table 1. Ingredients and nutrient compositions of the experimental diet (\% as fed basis $)^{1}$.

\begin{tabular}{|c|c|c|c|c|}
\hline Ingredient & $\mathrm{CON}$ & PFR5 & PFR10 & PFR15 \\
\hline Corn & 39.22 & 37.85 & 35.17 & 32.17 \\
\hline Soybean meal (45.6\%) & 27.92 & 25.68 & 23.58 & 21.58 \\
\hline Cassava meal & 15 & 15 & 15 & 15 \\
\hline Rice bran & 10 & 10 & 10 & 10 \\
\hline Rice bran oil & 5 & 5 & 5 & 5 \\
\hline Pickle fish residue & 0 & 5 & 10 & 15 \\
\hline L-Lysine (78\%) & 0.47 & 0.47 & 0.47 & 0.47 \\
\hline DL-Methionine (99\%) & 0.31 & 0.31 & 0.31 & 0.31 \\
\hline L-Threonine (99\%) & 0.22 & 0.22 & 0.22 & 0.22 \\
\hline Salt & 0.22 & 0.22 & - & - \\
\hline Limestone & 1.39 & - & - & - \\
\hline Vitamin-mineral premix ${ }^{2}$ & 0.25 & 0.25 & 0.25 & 0.25 \\
\hline Total & 100 & 100 & 100 & 100 \\
\hline \multicolumn{5}{|l|}{$\begin{array}{c}\text { Calculated compositions } \\
(\%)\end{array}$} \\
\hline $\begin{array}{c}\text { Metabolizable energy } \\
(\mathrm{kcal} / \mathrm{kg})\end{array}$ & 3400 & 3400 & 3400 & 3400 \\
\hline Crude protein & 18.50 & 18.50 & 18.50 & 18.50 \\
\hline Ether extract & 3.36 & 3.35 & 3.29 & 3.22 \\
\hline Lysine & 1.12 & 1.12 & 1.12 & 1.12 \\
\hline Methionine + Cysteine & 0.72 & 0.69 & 0.66 & 0.64 \\
\hline Threonine & 0.88 & 0.84 & 0.81 & 0.75 \\
\hline Tryptophan & 0.19 & 0.19 & 0.19 & 0.19 \\
\hline Calcium & 0.66 & 0.86 & 1.58 & 2.31 \\
\hline Total phosphorus & 0.53 & 0.86 & 1.18 & 1.51 \\
\hline $\mathrm{NaCl}$ & 0.43 & 0.43 & 0.43 & 0.65 \\
\hline Fiber & 4.83 & 5.08 & 5.30 & 5.52 \\
\hline \multicolumn{5}{|l|}{ Analyzed compositions (\%) } \\
\hline Crude protein & 18.57 & 18.52 & 18.49 & 18.54 \\
\hline Ether extract & 3.41 & 3.35 & 3.32 & 3.29 \\
\hline Crude fiber & 5.13 & 5.22 & 5.24 & 5.37 \\
\hline $\mathrm{NaCl}$ & 0.41 & 0.44 & 0.43 & 0.62 \\
\hline
\end{tabular}

${ }^{1}$ Calculated values of ingredient composition data were obtained from our laboratory analysis and NRC (2012). ${ }^{2}$ Provided (per $\mathrm{kg}$ of diet): 1,600,000 IU vitamin A, 400,000 IU vitamin $\mathrm{D}_{3}, 2200 \mathrm{IU}$ vitamin E, $0.3 \mathrm{~g}$ vitamin $\mathrm{K}_{3}, 0.2$ $\mathrm{g}$ vitamin $\mathrm{B}_{1}, 0.80 \mathrm{~g}$ vitamin $\mathrm{B}_{2}, 0.2 \mathrm{~g}$ vitamin $\mathrm{B}_{6}, 2.4 \mathrm{mg}$ vitamin $\mathrm{B}_{12}, 2 \mathrm{~g}$ pantothenic acid, $3 \mathrm{~g}$ nicotinic acid, $60 \mathrm{~g}$ choline chloride, $50 \mathrm{mg}$ biotin, $30 \mathrm{~g}$ Fe as $\mathrm{FeSO}_{4}, 0.2 \mathrm{~g} \mathrm{Co}$ as $\mathrm{CoSO}_{4}, 8 \mathrm{~g} \mathrm{Mn}$ as $\mathrm{MnSO}_{4}, 32 \mathrm{~g} \mathrm{Cu}$ as CuSO $4,20 \mathrm{~g} \mathrm{Zn}$ as $\mathrm{ZnSO}_{4}, 0.2 \mathrm{~g}$ I as KI, $0.02 \mathrm{~g}$ Se as $\mathrm{Na}_{2} \mathrm{SeO}_{3}, 10 \mathrm{~g}$ ethoxyquin, and $2 \mathrm{~g}$ silicon dioxide. 


\subsection{Growth Performance}

Pigs were weighed individually at the initiation and termination periods (6 weeks) of the experimental trial. The amount of feed administered to the pigs was recorded and corrected for residual feed, and was further used to calculate average daily gain (ADG), average daily feed intake (ADFI), and gain-to-feed ratio (G:F).

\subsection{Nutrient Digestibility}

Twelve castrated pigs (average body weight, $28.31 \pm 0.87 \mathrm{~kg}$ ) were chosen to determine nutrient digestibility using a total collection method. The pigs were assigned to individual metabolic crates in a completely randomized design, with three replicates per treatment, to collect faecal samples. The diets were administered twice daily at $12-\mathrm{h}$ intervals during the 7-day feeding period (four days for acclimation and three days for faecal collection). Chromic oxide (5 g/100 g of feed) was mixed in the experimental diet as an indigestible marker [10]. The faeces were placed in sealed-plastic bags and dried in an air-forced oven at $60{ }^{\circ} \mathrm{C}$ for $72 \mathrm{~h}$ prior to weighing. Thereafter, these representative samples and diets were ground with a grinding mill (Wiley Mill, Arthur H. Thomas Co., Philadelphia, PA, USA) to obtain a particle size of $0.88 \mathrm{~mm}$ for further analyses of dry matter (\#procedure 930.15, forced dried in oven at $135^{\circ} \mathrm{C}$ for $2 \mathrm{~h}$ ), CP (\#procedure 984.13; $\mathrm{N} \times 6.25$, using a combustion method), ash (\#procedure 942.15, muffle furnace at $600{ }^{\circ} \mathrm{C}$ for $2 \mathrm{~h}$ ), and EE (\#procedure 920.39, Soxhlet apparatus). All analysed procedures were performed according to the standard protocols [7]. The apparent total tract digestibility was calculated using the equation of Adeola [11].

\subsection{Blood Profiles}

When pigs were 13 and 16 weeks old (a three-week interval), blood (5 mL) was collected via jugular vein puncturing using a sterilized syringe with needle (BD Vacutainer, Plymouth, MA, UK). At the termination of the experiment, pigs (six pigs per treatment) with a BW almost equal to the average BW of the different pens were euthanized, and their blood, and intestinal segment were immediately collected for later analyses of blood profile, and intestinal morphology. The collected blood was transferred to a laboratory and subsequently centrifuged at $13,000 \times g$ for $15 \mathrm{~min}$ at $4{ }^{\circ} \mathrm{C}$ to obtain serum. Fifty microliters of sample and standard $(5 \mu \mathrm{L}$ of the $500 \mathrm{mM}$ calcium standard in $495 \mu \mathrm{L}$ of distilled water) were dispensed in each well after the addition of 90 and $60 \mu \mathrm{L}$ of the chromogenic reagent and calcium assay, respectively. To assay phosphorus content, the sample $(50 \mu \mathrm{L})$ and standard $(100 \mu \mathrm{L})$ were dispensed into each well, followed by the reaction mixture (50 $\mu \mathrm{L}$ comprising $43 \mu \mathrm{L}$ of assay buffer, $1 \mu \mathrm{L}$ of PicoProbe ${ }^{\mathrm{TM}}, 2 \mu \mathrm{L}$ of phosphate substrate, lyophilized converter, and lyophilized developer), and mixed immediately for $5 \mathrm{~min}$. Creatinine concentration was determined by preparing $50 \mu \mathrm{L}$ of standard, sample, and reagent mixture $(44 \mu \mathrm{L}$ of creatinine assay buffer and $2 \mu \mathrm{L}$ of creatinase, creatinine enzyme, and creatine probe). All mixture solutions, except $\mathrm{Ca}(10 \mathrm{~min})$, were incubated at room temperature for $60 \mathrm{~min}$ before detection at an absorbance of $570 \mathrm{~nm}$ using a microplate reader. Alkaline phosphatase (ALP) activity was determined using the standards $(120 \mu \mathrm{L})$, sample $(80 \mu \mathrm{L})$, and stop solution $(20 \mu \mathrm{L})$, which were gently mixed for homogenization. Fifty microliters of $5 \mathrm{mM}$ p-nitrophenyl phosphate (pNPP) solution was dispensed in each well containing the sample, followed by $10 \mu \mathrm{L}$ of ALP solution. After 60 min of incubation at room temperature, $20 \mu \mathrm{L}$ of stop solution was added to each well and the absorbance was measured at $405 \mathrm{~nm}$. The concentration of aspartate amino transferase (AST) was determined by dispensing the sample $(20 \mu \mathrm{L})$, standard solution $(50 \mu \mathrm{L}$, $0.1 \mathrm{M}$ glutamate standard), and reagent mixture solution $(100 \mu \mathrm{L}$ containing $80 \mu \mathrm{L}$ of assay buffer, $2 \mu \mathrm{L}$ of lyophilized enzyme, $8 \mu \mathrm{L}$ of lyophilized developer, and $10 \mu \mathrm{L}$ of substrate) in each well prior to absorbance detection at $450 \mathrm{~nm}$. All blood metabolites were quantified using enzyme-linked immunosorbent assay kits (Abcam assay kits, Cambridge, UK) and analysed in triplicate to test variations. 


\subsection{Intestinal Morphology}

After slaughtering, one pig (per pen, in total of 20 pigs) was eviscerated along the midline to open the abdominal cavity, and their whole intestine and intestinal organs were excised. Intestinal segments of the duodenum (at $25 \mathrm{~cm}$ caudal from the pylorus junction) and jejunum (between the pylorus junction and ileo-caecal junction) were immediately collected. Ten centimetres of each section was cut longitudinally, flushed with phosphate saline solution, and placed in a neutral-buffered $(\mathrm{pH} 7.4)$ solution with $10 \%(v / v)$ formalin on a shaker for $72 \mathrm{~h}$. The samples were subsequently dehydrated with graded alcohol (ethanol and diaphanized with xylol) and embedded in paraffin wax at $65{ }^{\circ} \mathrm{C}$. Tissue samples were sliced with a rotary microtome (Leica RM2235, Wetzlar, Germany) into $5-\mu \mathrm{m}$ thick sections, mounted on a microscope slide, and stained with haematoxylin-eosin (H\&E staining, Sigma-Aldrich, St. Louis, MO, USA) for gross morphological assay. Villus height was examined from the villus tip to the villus-crypt junction and their associated crypt depth was determined from the villus-crypt junction to muscularis mucosa, using a compound light microscope (Olympus Biological Model CX31, Shinjuku, Tokyo, Japan) at $10 \times$ magnification. Ten intact and well-oriented villi per specimen were selected, and the average was used for statistical analysis. The ratio of villus height: crypt depth was calculated.

\subsection{Statistical Analysis}

The obtained data were analysed in a randomized complete block design using the GLM procedure of SAS software (version 9.4, SAS Institute, Inc., Cary, NC, USA). A pen was considered as the experimental unit for the growth performance criteria, whereas an individual pig was considered as the experimental unit for nutrient digestibility, blood profile, and intestinal morphology. Significant differences were determined by Duncan's new multiple range test using $p<0.05$. Furthermore, the linear and quadratic effects of the PFR content were analysed by orthogonal polynomial contrast. The probability for a tendency was declared at $p>0.05$ to $p<0.10$. The results are presented as the least square means \pm standard error of mean (SEM).

\section{Results}

\subsection{Nutrient Composition and Feed Evaluation}

The nutrient composition and feed evaluation of PFR are presented in Table 2. Before treatment, PFR had a high content of $\mathrm{NaCl}$, which accounted for approximately $26.99 \%$ of its content. However, the $\mathrm{NaCl}$ content was lower $(4.32 \%)$ after treatment than that prior to treatment. The major nutrient composition of PFR included ash (62.25\%), followed by crude protein $(22.80 \%)$, calcium $(14.68 \%)$, nitrogen-free extract $(11.03 \%)$, and phosphorus $(6.92 \%)$. The contents of ether extract, crude fibre, and gross energy had a minimal effect either before or after treatment. Based on scanning electron microscopy (magnifications of $100 \times$ and $500 \times$ ), the surface of untreated PFR was coated with salt (Figure 1). However, the soaking and stirring procedures eliminated the excessive salt content on the PFR's surface (Figure 2).

Table 2. Analysed nutrient composition and feed evaluation of pickled fish residue (\% as fed basis).

\begin{tabular}{ccc}
\hline Item & Before Treating & After Treating \\
\hline Moisture & 1.98 & 1.47 \\
Ash & 61.12 & 62.25 \\
Crude protein & 20.52 & 22.80 \\
Ether extract & 1.45 & 1.58 \\
Crude fiber & 0.86 & 0.87 \\
Nitrogen free extract & 14.07 & 11.03 \\
Calcium $^{\text {Phosphorus }}$ & 12.95 & 14.68 \\
\hline
\end{tabular}


Table 2. Cont.

\begin{tabular}{ccc}
\hline Item & Before Treating & After Treating \\
\hline Gross energy $(\mathrm{kcal} / \mathrm{kg})$ & 2261.84 & 2685.60 \\
$\mathrm{NaCl}$ & 26.99 & 4.32 \\
Color score 2 & & \\
$L^{*}$ & 52.85 & 51.64 \\
$a^{*}$ & 7.53 & 7.59 \\
$b^{*}$ & 13.34 & 16.46 \\
\hline
\end{tabular}

${ }^{1} 100-(\%$ Moisture $+\% \mathrm{EE}+\% \mathrm{CP}+\%$ Ash $+\% \mathrm{CF}) .{ }^{2} L=$ lightness, $a=$ redness, $b=$ yellowness.

(A)

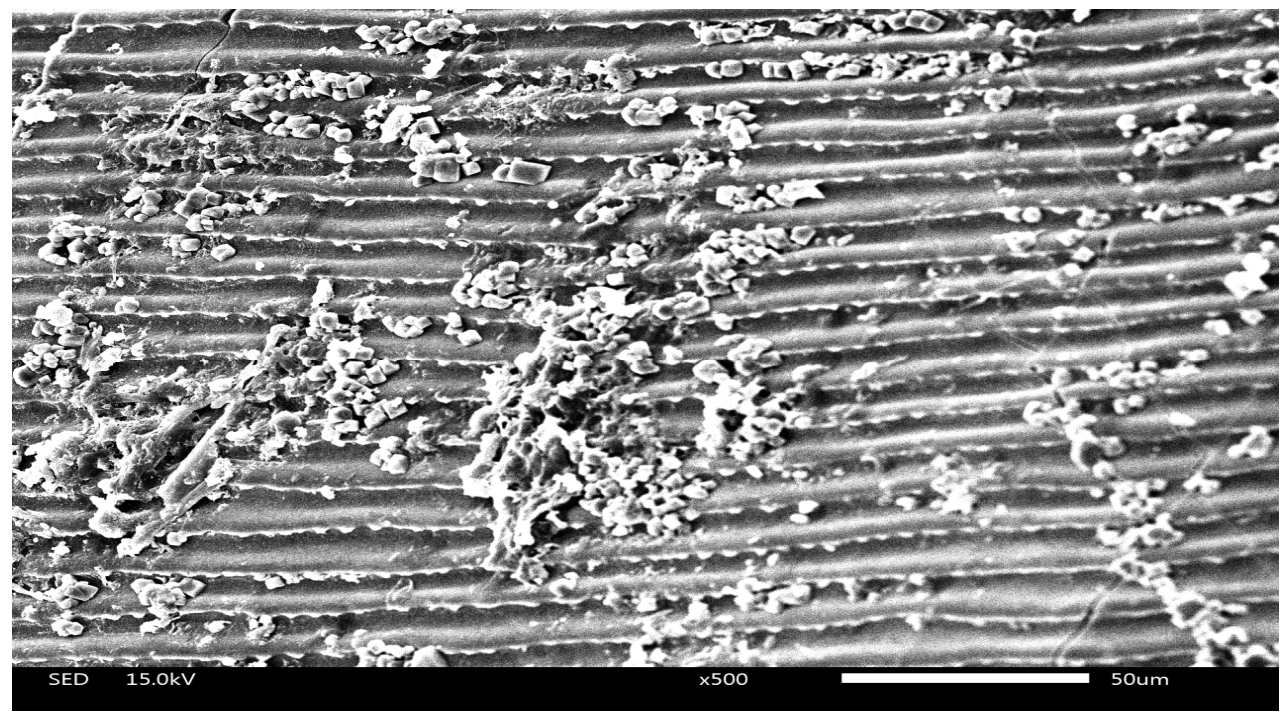

(B)

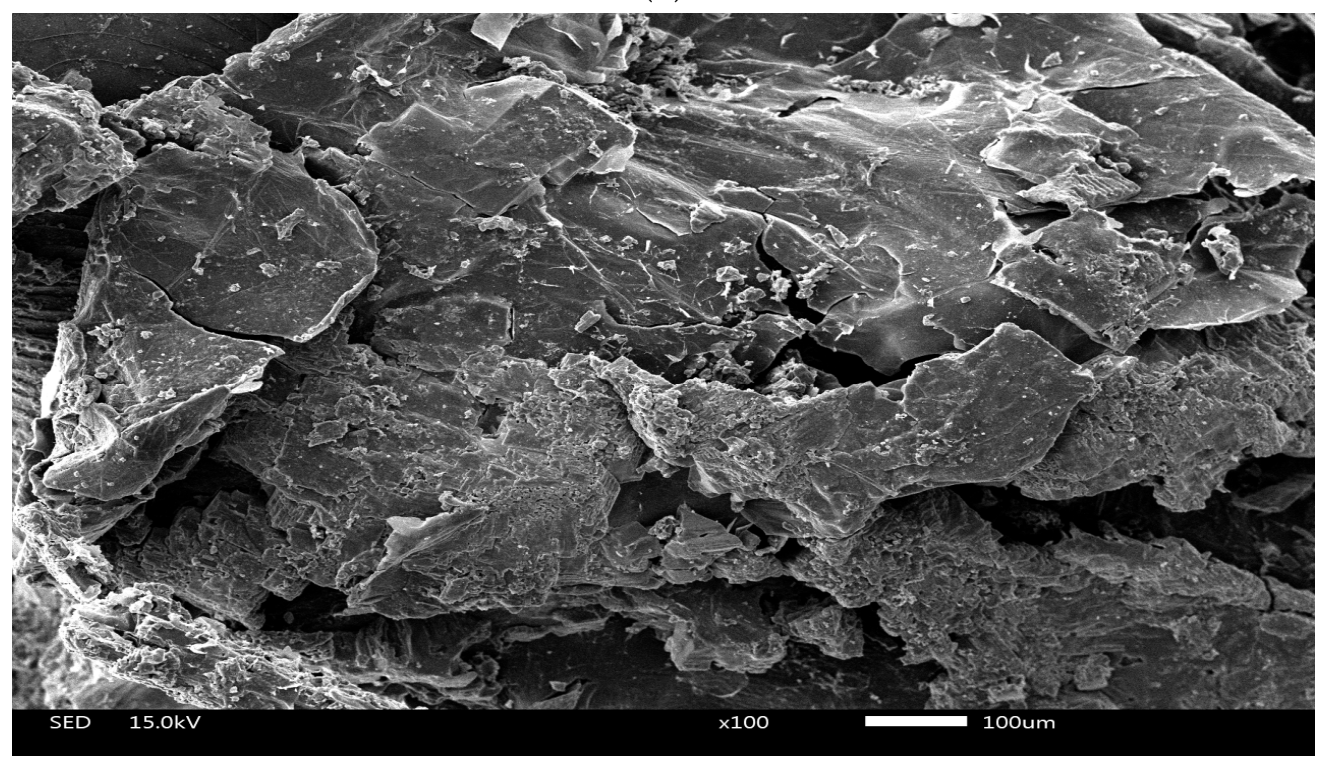

Figure 1. Scanning electron micrographs represents salt crystal ((A); 500 $\times)$ and transverse ((B); $100 \times)$ view of ground PFR in untreated sample with a scale bar of 50 and $100 \mu \mathrm{m}$, respectively. 
(A)

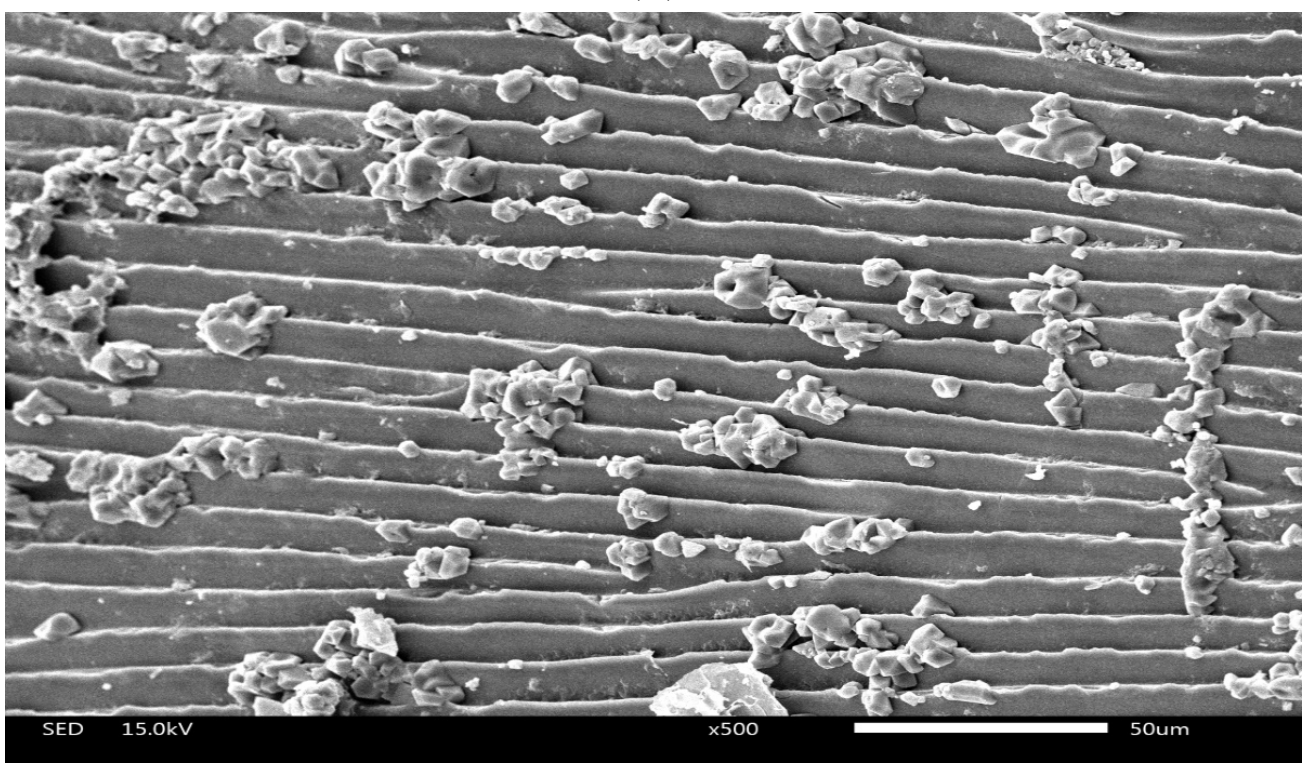

(B)

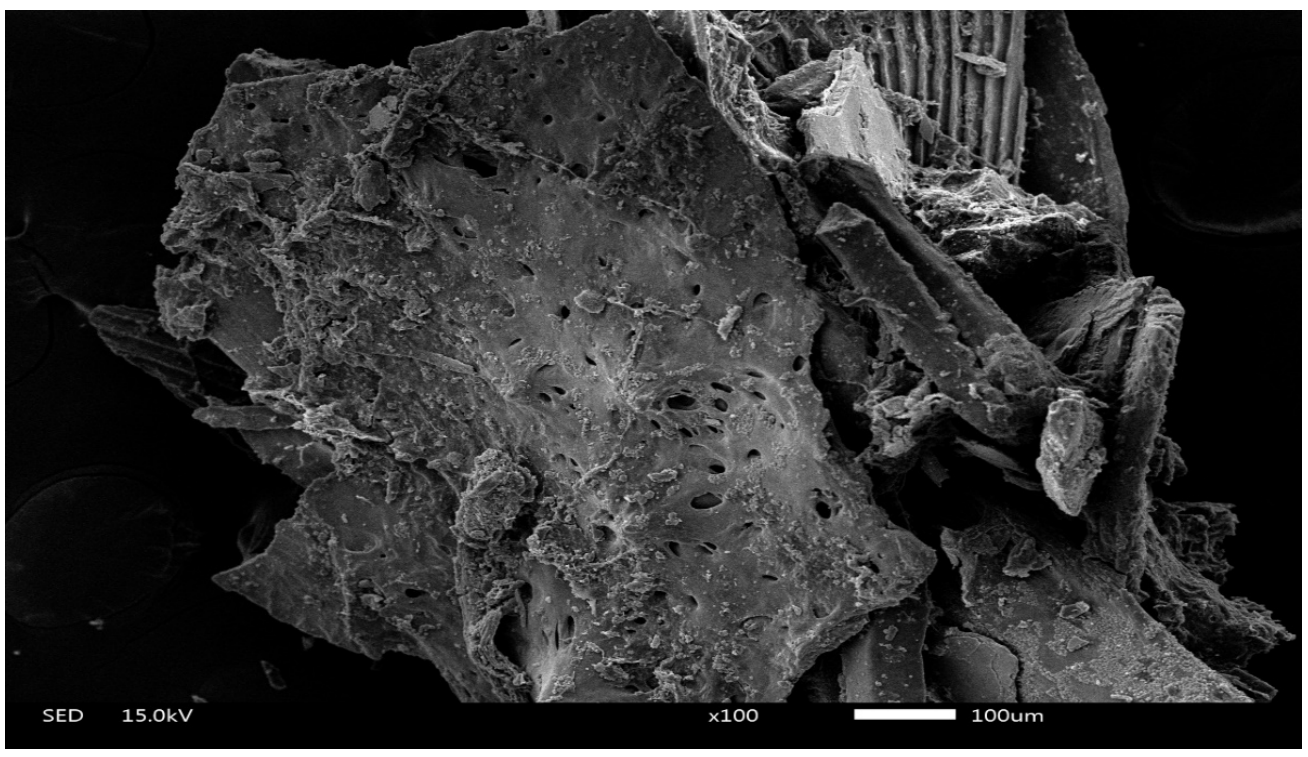

Figure 2. Scanning electron micrographs represents salt crystal ((A); 500 $\times)$ and transverse $((\mathbf{B}) ; 100 \times)$ view of ground PFR in treated sample with a scale bar of 50 and $100 \mu \mathrm{m}$, respectively.

\subsection{Growth Performance}

After 6 weeks of diet intake, growing pigs fed PFR10 had a greater G:F ratio (improvement $=11.6 \%)$ than those fed the CON diet $(p=0.027$, Table 3). Additionally, quadratic responses for final BW $(p=0.072)$, ADG $(p=0.078)$, and G:F $(p=0.013)$ were found as the PFR content increased. However, dietary treatment had no influence on ADFI.

\subsection{Nutrient Digestibility}

The linear and quadratic effects of increasing PFR content improved the digestibility of $\mathrm{CP}(p=0.012$ and $p=0.005$, respectively) and $\mathrm{EE}(p=0.028$ and $p=0.014$, respectively; Table 4). Furthermore, $10 \%$ PFR in the diet had the highest on both factors than CON, with increases of 3.47 and $7.21 \%$, respectively ( $p=0.006$ and $p=0.021$, respectively). However, no significant effects on DM and ash digestibility. 
Table 3. Effect of dietary PFR supplementation on growth performance of the growing pigs ${ }^{1,2}$.

\begin{tabular}{|c|c|c|c|c|c|c|c|c|}
\hline \multirow{2}{*}{ Item } & \multicolumn{4}{|c|}{ Dietary Supplement Level } & \multirow{2}{*}{ SEM } & \multicolumn{3}{|c|}{$p$-Value } \\
\hline & CON & PFR5 & PFR10 & PFR15 & & Treatment & Linear & Quadratic \\
\hline Number of pigs & 24 & 24 & 24 & 24 & & & & \\
\hline Initial BW (kg) & 23.48 & 23.73 & 23.67 & 23.73 & 0.243 & 0.861 & - & - \\
\hline Final BW (kg) & 48.49 & 49.89 & 50.82 & 49.67 & 1.619 & 0.141 & 0.150 & 0.072 \\
\hline ADG $(\mathrm{g})$ & 595.48 & 622.98 & 646.55 & 617.54 & 14.951 & 0.162 & 0.199 & 0.078 \\
\hline ADFI (g) & 1471 & 1447 & 1433 & 1459 & 26.191 & 0.769 & 0.688 & 0.354 \\
\hline G:F ratio & $0.405^{b}$ & $0.431^{\mathrm{a}, \mathrm{b}}$ & $0.452^{\mathrm{a}}$ & $0.423^{\mathrm{a}, \mathrm{b}}$ & 0.010 & 0.027 & 0.101 & 0.013 \\
\hline
\end{tabular}

${ }^{1}$ Control without PFR supplementation (CON); Basal diet with the PFR 5 (PFR5), 10 (PFR10), and 15\% (PFR15) supplementations, respectively. ${ }^{2}$ Values shows means of six replicates (pen) per treatment. ${ }^{\mathrm{a}, \mathrm{b}}$ Values with in rows without a common superscript are differ significantly $(p<0.05)$.

Table 4. Effect of dietary PFR supplementation on apparent total tract digestibility of the growing pigs ${ }^{1,2}$.

\begin{tabular}{|c|c|c|c|c|c|c|c|c|}
\hline \multirow{2}{*}{ Item } & \multicolumn{4}{|c|}{ Dietary Supplement Level } & \multirow{2}{*}{ SEM } & \multicolumn{3}{|c|}{$p$-Value } \\
\hline & $\mathrm{CON}$ & PFR5 & PFR10 & PFR15 & & Treatment & Linear & Quadratic \\
\hline Number of pigs & 3 & 3 & 3 & 3 & & & & \\
\hline \multicolumn{9}{|c|}{ Apparent total tract digestibility (\%) } \\
\hline Dry matter & 92.59 & 93.03 & 93.53 & 93.15 & 0.416 & 0.495 & 0.272 & 0.353 \\
\hline Crude protein & $89.57^{\mathrm{c}}$ & $92.18^{\mathrm{a}, \mathrm{b}}$ & $93.97^{\mathrm{a}}$ & $91.89^{b}$ & 0.623 & 0.006 & 0.012 & 0.005 \\
\hline Ash & 46.74 & 53.45 & 55.61 & 51.96 & 4.007 & 0.484 & 0.347 & 0.228 \\
\hline Ether extract & $77.81^{\mathrm{b}}$ & $83.25^{\mathrm{a}}$ & $84.69^{a}$ & $82.32^{a}$ & 1.274 & 0.021 & 0.028 & 0.014 \\
\hline
\end{tabular}

${ }^{1}$ Control without PFR supplementation (CON); Basal diet with the PFR 5 (PFR5), 10 (PFR10), and 15\% (PFR15) supplementations, respectively. ${ }^{2}$ Mean values represent three pigs per treatment with the body weight of $28.31 \pm 0.87 \mathrm{~kg}(\mathrm{n}=12) .{ }^{\mathrm{a}-\mathrm{c}}$ Means within a row without a common superscript are differ significantly $(p<0.05)$.

\subsection{Blood Profiles}

The change in AST concentration was linearly increased ( $p=0.053)$, but no difference between PFR10 and CON at week 3. PFR15 was also found to induce effects at week 6 $(p=0.034$; Table 5). The increasing level of PFR was found to have linearly and quadratic effects on AST concentration at week 13 ( $p=0.053$ and $p=0.034$, respectively); however, only a quadratic effect was found at 16 weeks of age in response to increasing levels of PFR ( $p=0.051)$. The concentrations of total Ca, phosphorus, creatinine, and ALP were not found to be affected by the PFR content.

Table 5. Effect of dietary PFR supplementation on blood profiles of the growing pigs ${ }^{1,2}$.

\begin{tabular}{|c|c|c|c|c|c|c|c|c|}
\hline \multirow{2}{*}{ Item } & \multicolumn{4}{|c|}{ Dietary Supplement Level } & \multirow{2}{*}{ SEM } & \multicolumn{3}{|c|}{$p$-Value } \\
\hline & CON & PFR5 & PFR10 & PFR15 & & Treatment & Linear & Quadratic \\
\hline $\begin{array}{c}\text { Number of pigs } \\
3 \text { weeks }\end{array}$ & 5 & 5 & 5 & 5 & & & & \\
\hline Total Ca (mmol/L) & 2.54 & 2.63 & 2.61 & 2.71 & 5.581 & 0.930 & 0.562 & 0.982 \\
\hline $\begin{array}{c}\text { Phosphorus } \\
(\mathrm{mmol} / \mathrm{L})\end{array}$ & 3.08 & 2.97 & 3.18 & 2.92 & 3.416 & 0.926 & 0.844 & 0.803 \\
\hline $\begin{array}{l}\text { Creatinine } \\
(\mu \mathrm{mol} / \mathrm{L})\end{array}$ & 119.97 & 127.83 & 122.83 & 116.17 & 0.086 & 0.909 & 0.758 & 0.543 \\
\hline $\operatorname{ALP}(\mathrm{U} / \mathrm{L})$ & 420.33 & 453.88 & 392.57 & 456.17 & 0.022 & 0.736 & 0.826 & 0.749 \\
\hline AST (U/L) & $68.34^{b}$ & $70.67^{b}$ & $58.43^{\mathrm{b}}$ & $96.18^{a}$ & 0.132 & 0.019 & 0.053 & 0.034 \\
\hline
\end{tabular}


Table 5. Cont.

\begin{tabular}{|c|c|c|c|c|c|c|c|c|}
\hline \multirow{2}{*}{ Item } & \multicolumn{4}{|c|}{ Dietary Supplement Level } & \multirow{2}{*}{ SEM } & \multicolumn{3}{|c|}{$p$-Value } \\
\hline & CON & PFR5 & PFR10 & PFR15 & & Treatment & Linear & Quadratic \\
\hline 6 weeks & & & & & & & & \\
\hline Total Ca $(\mathrm{mmol} / \mathrm{L})$ & 2.62 & 2.54 & 2.69 & 2.74 & 7.022 & 0.785 & 0.454 & 0.663 \\
\hline $\begin{array}{c}\text { Phosphorus } \\
\text { (mmol/L) }\end{array}$ & 2.87 & 3.04 & 3.19 & 3.13 & 3.222 & 0.894 & 0.512 & 0.722 \\
\hline $\begin{array}{l}\text { Creatinine } \\
(\mu \mathrm{mol} / \mathrm{L})\end{array}$ & 131.83 & 121.67 & 130.50 & 124.33 & 0.136 & 0.727 & 0.683 & 0.789 \\
\hline $\operatorname{ALP}(\mathrm{U} / \mathrm{L})$ & 444.77 & 427.83 & 469.39 & 432.83 & 0.019 & 0.942 & 0.981 & 0.853 \\
\hline AST (U/L) & $79.25^{\mathrm{a}, \mathrm{b}}$ & $81.82^{a, b}$ & $69.39^{b}$ & $98.92^{\mathrm{a}}$ & 0.158 & 0.034 & 0.122 & 0.051 \\
\hline
\end{tabular}

${ }^{1} \mathrm{ALP}=$ alkaline phosphatase, $\mathrm{AST}=$ aspartate aminotransferase, Control without PFR supplementation $(\mathrm{CON})$ Basal diet with the PFR 5 (PFR5), 10 (PFR10), and 15\% (PFR15) supplementations, respectively. ${ }^{2}$ Mean values from six replicate pens with one pig per replicate pen $(n=24) .{ }^{a, b}$ Mean within a row without a common superscript are differ significantly $(p<0.05)$.

\subsection{Intestinal Morphology}

Dietary PRF inclusion significantly increased villus height in the duodenum by $26.05 \%$ $(p=0.004)$ and significantly decreased crypt depth in the jejunum by $11.74 \%(p=0.012)$ compared to CON (Table 6). Additionally, growing pigs fed increasing levels of PRF tended to display a linear increase in villus height $(p=0.001)$ and villus height: crypt depth ratio $(p=0.015$ and $p=0.044)$, and a decrease in crypt depth in the jejunum $(p=0.002)$. However, a PRF content greater than $10 \%$ tended to reduce the villus height: crypt depth ratio $(p=0.051)$. No differences were observed in jejunal villus height and duodenal crypt depth following the different dietary treatments.

Table 6. Effect of dietary PFR supplementation on intestinal morphology of the growing pigs ${ }^{1,2}$.

\begin{tabular}{|c|c|c|c|c|c|c|c|c|}
\hline \multirow{2}{*}{ Item } & \multicolumn{4}{|c|}{ Dietary Supplement Level } & \multirow{2}{*}{ SEM } & \multicolumn{3}{|c|}{$p$-Value } \\
\hline & $\mathrm{CON}$ & PFR5 & PFR10 & PFR15 & & Treatment & Linear & Quadratic \\
\hline Number of pigs & 5 & 5 & 5 & 5 & 5 & & & \\
\hline \multicolumn{9}{|l|}{ Villus height $(\mu \mathrm{m})$} \\
\hline Duodenum & $263.79^{c}$ & $309.03^{b}$ & $330.59^{a, b}$ & $357.93^{a}$ & 14.275 & 0.004 & 0.001 & 0.542 \\
\hline Jejunum & 326.37 & 341.94 & 349.53 & 321.68 & 15.503 & 0.565 & 0.927 & 0.187 \\
\hline \multicolumn{9}{|l|}{ Crypt depth $(\mu \mathrm{m})$} \\
\hline Duodenum & 215.39 & 200.17 & 193.01 & 219.23 & $12 . .930$ & 0.460 & 0.941 & 0.135 \\
\hline Jejunum & $232.02^{a}$ & $212.58^{b}$ & $204.08^{b}$ & $197.71^{b}$ & 6.255 & 0.012 & 0.002 & 0.317 \\
\hline \multicolumn{9}{|c|}{ Villus height:crypt depth } \\
\hline Duodenum & 1.23 & 1.57 & 1.72 & 1.69 & 0.122 & 0.053 & 0.015 & 0.166 \\
\hline Jejunum & 1.41 & 1.63 & 1.72 & 1.62 & 0.073 & 0.059 & 0.044 & 0.051 \\
\hline
\end{tabular}

${ }^{1}$ Control without PFR supplementation (CON); Basal diet with the PFR 5 (PFR5), 10 (PFR10), and 15\% (PFR15) supplementations, respectively. ${ }^{2}$ Mean values from five replicate pens with one pig per replicate pen $(n=20)$. ${ }_{a-c}$ Means within a row without a common superscript are differ significantly $(p<0.05)$.

\section{Discussion}

\subsection{Nutrient Composition and Feed Evaluation}

Sodium chloride $(\mathrm{NaCl})$ plays a vital role in various metabolic and physiological functions, including energy utilization, cell differentiation, cell signalling, nutrient metabolism, as well as controlled osmotic pressure and acid-based balance [12]. Excessive intake of $\mathrm{NaCl}$ causes toxicity, including nervous disorders, weakness, staggering, poor sperm quality, epileptic seizures, paralysis, and even death $[9,13]$. PFR should have a lower $\mathrm{NaCl}$ content before it is administered to pigs, as high contents cause toxicity, and impair growth rate and health status. Fereidoun et al. [14] revealed salt toxicity when the salt content was greater than $1.4 \%$. To alleviate toxicity, the salt should be dissolved by mixing with water, enabling the interaction of the ion $\left(\mathrm{Na}^{+}\right.$or $\left.\mathrm{Cl}^{-}\right)$with an ionic water molecule, resulting in a 
homogenous solution [15]. Stirring and speed may rapidly increase the rate of solubility by allowing greater interactions, owing to the lower amount of $\mathrm{NaCl}$ on the PFR surface. In this study, the amount of salt in PFR was higher than that found by Mielcarek et al. [16], who observed salt content ranging from 1.47 to $2.29 \%$. The difference in the result is associated with differences in the fish species, origin, and pickled fish process. According to a recent investigation of the optimal $\mathrm{NaCl}$ dosage in feed formulation, the pigs can utilize $0.40 \%$ of $\mathrm{NaCl}$, which subsequently enhances $\mathrm{P}$ absorption and its digestibility via coupling $\mathrm{Na}^{+}$transportation to $\mathrm{P}_{\mathrm{i}}$ absorption as a cotransporter [17]. The improvement of $P$ digestibility may be more relevant in older pigs than younger pigs. Mielcarek et al. [16] reported that the crude protein and energy contents in PFR were higher than those in eight freshwater fish species.

As per feed evaluation, the colour of treated PFR slightly became dark due to the use of high drying temperatures, which contributes to discoloration of the fish by-product [18]. However, the $L^{*}$ value was almost unchanged. Thus, the boiling temperature of $60{ }^{\circ} \mathrm{C}$ for pickled fish might inhibit discolouration of the non-enzymatic browning reaction. Furthermore, the colour of the PFR meal became yellow, which is the preferred colour for feed manufacturing, as it contributes to the attitude of pigs towards eating [19].

\subsection{Growth Performance}

Chemical analysis of PFR revealed relatively high levels of CP and nitrogen-free extract. These positive outcomes in promoting growth performance of growing pigs may increase the amount of amino acids and monosaccharides. These findings also align with those of Noh et al. [20], who demonstrated that weaned pigs fed 5\% fish by-product had significantly improved feed efficiency, as well as improved ADFI and G:F ratio. It seems that the growing pigs showed the highest G:F ratio, which was sufficient to secrete several digestive enzymes [21]. This is consistent with our finding. Such finding also aligns with that of Richart et al. [6], who observed that the consumption of $10 \%$ tilapia filleting waste meal by growing pigs (15 to $30 \mathrm{~kg}$ BW) did not have any detrimental effects on their growth performance. However, up to $15 \%$ of tilapia filleting waste in the diet caused a decrease in final BW, ADG, and ADG. The quadratic reduction in these criteria with increasing dietary PFR could be associated with the loss of essential nutrients in the diet formulation after its industrial processing. Heat treatment is commonly used in the preparation of filleting waste fish meal, which can block amino acids (e.g., lysine and arginine) and reducing sugars (e.g., fructose and glucose) owing to their high susceptibility to the Millard reaction [22]. In addition, the long storage of fish residue causes increases in harmful bacterial activity, which subsequently increases the content of biogenic amines. A further study is needed to clarify the adverse effect of long-term storage of PFR before use in livestock feed. A previous study revealed that the desirable odour of PFR increased feed palatability by improving ADFI [23]; however, such influence was not observed in the present study. The discrepancy might be caused by differences in freshwater fish source, batches, and storage duration, which influences the quality and nutritional composition of PFR. Therefore, the improved G:F ratio obtained upon termination of the feeding trial may contribute to higher nutrient digestibility and better gut health status of growing pigs.

\subsection{Nutrient Digestibility}

The PFR used in the current trial has higher protein $(22.80 \%)$ and a lower fibre $(0.87 \%)$ contents that can be more efficiently utilized by older pigs, inducing higher digestibility of the crude protein. The improvement of crude protein digestibility by fish waste inclusion was previously confirmed in aquaculture [24]. Although the amount of the EE is relatively low in PFR (1.58\%), this amount was comparable to that in soybean meal [9], which has relatively high quantities of polyunsaturated fatty acids (PUFA). The superior digestibility of fish oil rich in linoleic acid, eicosapentaenoic acid, and docosahexaenoic acid, has been established to cause more efficient incorporation of PUFA into micelles for better fat utilization [25]. The increased digestibility of the CP and EE could be attributed to 
the change in intestinal morphology and functions. The extent of nutrient uptake in the intestine is mainly dependent on the interplay between digestive and absorptive efficiency at the brush border and intestinal epithelial permeability [26]. This proposal agrees with the higher villus and shorter crypt depth found in this study. However, a quadratic response on the lower digestibility of CP and EE was found when the PFR content was higher than $15 \%$. One reason may be the influence of the high ash content that may cause contamination with undesirable substances [7]. In our study, the phosphorus content in PFR was 6.92\%, which may cause an imbalance in the ratio of $\mathrm{K}^{+}$and $\mathrm{Na}^{+}$to $\mathrm{Cl}^{+}$in the animal body, ultimately leading to reduced phosphorus absorption [27]. Variations in the pickled fish process, freshwater fish species, storage condition, and duration may have a detrimental effect, inducing a poor quality PFR [16]. The insufficiency of essential amino acids, excess salt content, toxins, and foreign substance leads to poor protein utilization, and therefore decreased growth rate and feed efficiency. Hence, a high dietary PFR content (15\%) may limit their use as a feed ingredient for growing pigs. Further studies are required to confirm this notion.

\subsection{Blood Profiles}

Blood metabolites are measurable biomarkers. Consequently, their abundance and impact on the health status of humans and animals can be determined. Calcium (Ca) and phosphorus (P) are two abundant elements in pigs that are essential for development, maintenance of homeostasis of the skeletal system, and many physiological functions [28]. Growing pigs fed a PFR-supplemented diet had no alterations in total $\mathrm{Ca}^{2+}$ and $\mathrm{P}$ concentrations during the experimental period. Ebeledike et al. [29] demonstrated that the animals can regulate the continuous supply of $\mathrm{Ca}$ in the body. However, a short feeding period may not be able to reveal significant differences in ADFI, which may justify the lack of remarkable changes in mineral intake, absorption, and excretion. Creatinine undergoes metabolic breakdown in muscle cells, accumulates in the bloodstream, fills the kidneys, and is excreted via urination. Excessive amounts of creatinine, including the metabolic activities of ALP and AST concentrations, can also induce renal and hepatic toxicity [30]. Of note, up to $10 \%$ PFR did not alter PFR-induced liver damage; however, pigs became less tolerant as PFR contents increased to levels that were over $15 \%$ but within the normal range [31,32]. Such findings may be due to variations in diet composition, particularly regarding protein quality. Previous report revealed that most animal protein by-products have a high content of biogenic amines, which directly pass through systemic circulation and exert their toxicity in various organs as signs of health dysfunctions, either at the genetic or intake inhibitory levels [33]. The activity of liver enzymes that could influence acute hepatotoxicity in the pig in response to PFR supplementation should be determined.

\subsection{Intestinal Morphology}

The integrity of the intestinal epithelium not only protects against pathogen invasions, but also enables nutrient uptake [26]. Three fundamental morphological indicators are commonly used to determine the overall health and function of the small intestine: villus height, crypt depth, and villus height: crypt depth ratio. A longer villus height increases the luminal villus absorptive area and induces satisfactory digestible enzyme functions, as well as available nutrients [34]. A shorter crypt depth designates a lower metabolic rate of epithelium turnover, whereas a deeper crypt depth indicates rapid tissue turnover for villi renewal, in response to the higher secretion of pro-inflammatory cytokines induced by pathogens and harmful substances. A greater villus height: crypt depth ratio has a significant influence on nutrient absorption and decreased inflammation, which might promote growth performance [35]. Our findings revealed increases in villus height owing to the PFR-supplemented diet, which may contribute to the higher digestibility of CP. However, the use of PFR in amino acid analysis performed in the preliminary study could not justify this finding. Therefore, further studies are needed to clarify the amino acid compositions prior to the supplementation of PFR as a novel feed ingredient in 
livestock feed. Additionally, a proper content of crude fibre enables its utilization by the digestive enzymes in the duodenum [36], owing to a higher villus height. The PFR caused a reduction in crypt depth in the jejunum rather than the duodenum. According to a previous study, several enteric pathogens can impair the jejunal integrity of growing pigs, thereby altering the secretion of pro-inflammatory cytokines [37]. Buchon et al. [38] revealed that pathogens can induce epithelial loss and activate the generation of new cells to replace damaged epithelial cells. Such findings are consistent with the longer crypt depth found in growing pigs fed a diet without PFR inclusion. However, the inclusion of PFR potentially enhanced the maturity of the apical enterocyte of growing pigs, which could regulate enterocyte migration and normal sloughing from pathogenic microbes. The lack of difference in crypt depth of the duodenum segment, owing to the dietary treatment, may be partially influenced by the greater capacity of older animals to achieve constant renewal of intestinal crypts. Interestingly, as the PFR content increased, there was a linear response on the increased ratio of villus height: crypt depth, which not only positively affects the satisfactory nutrient, but also inhibits intestinal atrophy. Therefore, the positive effect in morphologic indices in response to PFR supplementation could broaden the absorptive area of the small intestine, and enhance the digestion and absorption of nutrients. These benefits may be achieved via the activation of nutrient utilization, leading to the promotion of growth performance in growing pigs.

\section{Conclusions}

Decreasing salt content in PFR via soaking and stirring for 30 min could eliminate excessive salt from $26.99 \%$ to $4.32 \%$. Supplementation with $10 \%$ PFR had positive impacts on G:F ratio, $\mathrm{CP}$ and EE digestibility, villus height: crypt depth ratio, and caused reductions in crypt depth. The inclusion of $10 \%$ PFR is an appropriate level that could be considered as an alternative feed ingredient for growing pigs.

Author Contributions: Conceptualization, W.B.; Formal analysis, W.B., S.K., C.W. and J.H.; Funding acquisition, W.B.; Investigation, W.B., S.G. and A.S.; Project administration, W.B.; Supervision, C.W., S.K., S.G. and A.S.; Validation, W.B. and J.H.; Writing—original draft, W.B. and J.H.; Writing-review \& editing, W.B. and J.H. All authors have read and agreed to the published version of the manuscript.

Funding: This research receives funding from Program Management Unit for Competitiveness, Office of National Higher Education Science Research and Innovation Policy Council (grant no. C10F640112) under BCG in Action.

Institutional Review Board Statement: The study was reviewed and approved by the Institutional Animal Care and Use Committee of Khon Kaen University (\#IACUC-KKU61/64, approved on 17 June 2020, Khon Kaen, Thailand).

Informed Consent Statement: Not applicable.

Data Availability Statement: The data presented in this study are available in the manuscript.

Acknowledgments: The authors would like to sincerely thank Chok Anan Farm (Chaiyaphum, Thailand) and the Swine Farm Unit for providing the animals and research facility. The authors also thank Phetdam Food Co., Ltd. (Kalasin, Thailand) for the pickled fish residue.

Conflicts of Interest: All authors declare no potential conflict of interest.

\section{References}

1. Behera, S.S.; El-Sheikha, A.F.; Hammami, R.; Kumar, A. Traditionally fermented pickles: How the microbial diversity associated with their nutritional and health benefits? J. Funct. Foods 2020, 70, 103971. [CrossRef]

2. Rodpai, R.; Sanpool, O.; Thanchomnang, T.; Wangwiwatsin, A.; Sadaow, L.; Phupiewkham, W.; Boonroumkaew, P.; Intapan, P.M.; Mallewong, W. Investigating the microbiota of fermented fish products (Pla-ra) from different communities of northeastern Thailand. PLoS ONE 2020, 16, e0245227. [CrossRef]

3. Ogata, Y.; Ishigaki, T.; Nakagawa, M.; Yamada, M. Effect of increasing salinity on biogas production in waste landfills with leachate recirculation: A lab-scale model study. Biotechnol. Rep. 2016, 10, 111-116. [CrossRef] 
4. Thai Agricultural Standard TAS 7023-2018 "PLA-RA". Available online: https://www.acfs.go.th/standard/download/eng/ PLA-RA-ENG.pdf (accessed on 5 November 2021).

5. Shawk, D.J.; Goodband, R.D.; Tokach, M.D.; Dritz, S.S.; DeRouchey, J.M.; Woodworth, J.C.; Lerner, A.B.; Williams, H.E. Effects of added dietary salt on pig growth performance. Transl. Anim. Sci. 2018, 2, 396-406. [CrossRef] [PubMed]

6. Richart, E.; Nunes, R.V.; Castilha, L.D.; Silva, Y.L.; Cella, P.S. Nutritional evaluation of Tilapia filleting waste meal for swine in the nursery phase. Rev. Caatinga 2016, 29, 473-480. [CrossRef]

7. Association of Official Analytical Chemists (AOAC). Official Methods of Analysis, 17th ed.; AOAC International: Gaithersburg, MD, USA, 2000.

8. European Medicines Agency Regulation (EU) 2019/6 of the European Parliament and of the Council of 11 December 2018 on Veterinary Medicinal Products and Repealing Directive 2001/82/EC. Available online: https:/ / eur-lex.europa.eu/legal-content/ EN/TXT/PDF/?uri=CELEX:32019R0006\&from=EN (accessed on 21 November 2020).

9. National Research Council (NRC). Nutrient Requirement of Swine, 11th ed.; National Academic Press: Washington, DC, USA, 2012.

10. Wang, T.; Adeola, O. Digestibility index marker type, but not inclusion level affects apparent digestibility of energy and nitrogen markey recovery in growing pigs regardless of added oat bran. J. Anim. Sci. 2018, 96, 2817-2825. [CrossRef]

11. Adeola, O. Digestion and Balance Techniques in Pigs. In Swine Nutrition, 2nd ed.; Lewis, A.J., Southern, L.L., Eds.; CRC Press: Washington, DC, USA, 2001; pp. 903-916.

12. Wang, C.; Huang, Z.; Yu, K.; Ding, R.; Ye, K.; Dai, C.; Xu, X.; Zhou, G.; Li, C. High-salt diets has a certain impact on protein digestion and gut microbiota: A sequencing and proteome combined study. Front. Microbiol. 2017, 8, 1838. [CrossRef]

13. Abdelnour, S.A.; El-Hack, M.E.A.; Noreldin, A.E.; Batiha, G.E.; Beshbishy, A.M.; Ohran, H.; Khafaga, A.F.; Othman, S.I.; Allam, A.A.; Swelum, A.A. High salt diet affects the reproductive health in animals: An overview. Animals 2020, 10, 590. [CrossRef]

14. Fereidoun, H.; Bahram, A.; Sadraddin, K.; Ahmad, R.; Pouria, H. Determination of tolerable and toxic salt concentrations in drinking water in rat, pig, and rabbit. Toxicol. Environ. Chem. 2018, 90, 115-1123. [CrossRef]

15. Neves, C.M.S.S.; Held, C.; Mohammad, S.; Schleinitz, M.; Coutinhoa, J.A.P.; Freire, M.G. Effect of salts on the solubility of ionic liquid in water: Experimental and electrolyte Perturbed-Chain Statistical Associating Fluid Theory. Phys. Chem. Chem. Phys. 2015, 17, 32044-32052. [CrossRef]

16. Mielcarek, K.; Puścion-Jakubik, A.; Gromkowska-Kępka, K.J.; Soroczyńska, J.; Naliwajko, S.K.; Markiewicz-Żukowska, R.; Moskwa, J.; Nowakowski, P.; Borawska, M.H.; Socha, K. Proximal composition and nutritive value of raw, smoked and pickled freshwater fish. Foods 2020, 9, 1879. [CrossRef] [PubMed]

17. Yin, Y.; Huang, C.; Wu, X.; Li, T.; Huang, R.; Kang, P.; Hu, Q.; Chu, W.; Kong, X. Nutrient digestibility response to graded dietary levels of sodium chloride in weanling pigs. J. Sci. Food Agric. 2008, 88, 940-944. [CrossRef]

18. Duangsai, P.; Gawborisut, S. Effects of drying temperature on quality parameters of Thai fermented fish dip (Jaew Bong). Int. J. Food Stud. 2020, 9, 251-263. [CrossRef]

19. Klocek, C.; Nowicki, J.; Brudzisz, B.; Pabiańczyk, M. Color preferences in pigs. Sci. Ann. Polish Soc. Anim. Prod. 2016, 12, 123-129.

20. Noh, H.S.; Ingale, S.L.; Lee, S.H.; Kim, K.H.; Kwon, I.K.; Kim, Y.H.; Jo, C.B. Effects of citrus pulp, fish by-product and Bacillus subtilis fermentation biomass on growth performance, nutrient digestibility, and fecal microflora of weanling pigs. J. Anim. Sci. Technol. 2014, 56, 10. [CrossRef] [PubMed]

21. Jensen, M.S.; Jensen, S.K.; Jakobsen, K. Development of digestive enzymes in pigs with emphasis on lipolytic activity in the stomach and pancreas. J. Anim. Sci. 1997, 75, 437-445. [CrossRef]

22. Teodorowicz, M.; Hendriks, W.H.; Wichers, H.J.; Savelkoul, H.F.J. Immunomodulation by processed animal feed: The role of Millard reaction products and advanced glycation end-products (AGEs). Front. Immunol. 2018, 9, 2088. [CrossRef]

23. Lee, H.J.; Choi, I.H.; Kim, D.H.; Joo, Y.H.; Kim, S.C. Influence of fermented fish meal supplementation on growth performance, blood metabolites, and fecal microflora of weaning pigs. R. Braz. Zootec. 2017, 46, 433-437. [CrossRef]

24. Mmanda, F.P.; Lindberg, J.E.; Haldén, A.N.; Mtolera, M.S.P.; Kitula, R.; Lundh, T. Digestibility of local feed ingredients in Talipia Oreochromis niloticus jeveniles, determined on faeces collected by siphoning or stripping. Fishes 2020, 5, 32. [CrossRef]

25. Upadhaya, S.D.; Kim, I.H. Supplemental effects of fish oil and powdered/coated docosahexaenoic acid on the growth performance, nutrient digestibility, blood profile and fecal coliform and lactic acid bacteria counts in weaner pigs. Anim. Feed Sci. Technol. 2021, 275, 114885. [CrossRef]

26. Choct, M. Managing gut health through nutrition. Br. Poult. Sci. 2009, 50, 9-15. [CrossRef]

27. Becker, S.L.; Gould, S.A.; Petry, A.L.; Kellesvig, L.M.; Patience, J.F. Adverse effects on growth performance and bone development in nursery pigs fed diets marginally deficient in phosphorus with increasing calcium to available phosphorus ratios. J. Anim. Sci. 2020, 98, 1-8. [CrossRef]

28. Oster, M.; Just, F.; Büsing, K.; Wolf, P.; Polley, C.; Vollmar, B.; Muráni, E.; Ponsuksili, S.; Wimmers, K. Toward improved phosphorus efficiency in monogastrics-interplay of serum, minerals, bone, and immune system after divergent dietary phosphorus supply in swine. Am. J. Physiol. Regul. Integr. Comp. Physiol. 2016, 310, 917-925. [CrossRef]

29. Ebeledike, E.U.; Nwokedi, G.I.U.; Ndu, O.O.; Okoye, F.B.C.; Ochiogu, I.S. Calcium and phosphorus contents of body parts of some domestic animals used as meat source in Nigeria. Asian Pac. J. Trop. Med. 2010, 3, 395-398. [CrossRef]

30. Hasan, K.M.; Tamanna, N.; Haque, A. Biochemical and histopathological profiling of Wistar rat treated with Brassica napus as a supplementary feed. Food Sci. Hum. 2018, 7, 77-82. [CrossRef] 
31. Unger, V.; Grosse-Siestrup, C.; Fehrenberg, C.; Fischer, A.; Meissler, M.; Groneberg, D.A. Reference values and physiological characterization of a specific isolated pig kidney perfusion model. J. Occup. Med. Toxicol. 2007, 2, 1. [CrossRef] [PubMed]

32. Barszcz, M.; Taciak, M.; Tuśnio, A.; Ćobanová, K.; Grešáková, L. The effect of organic and inorganic zinc source, used in combination with potato fiber, on growth, nutrient digestibility and biochemical blood profile in growing pigs. Livest. Sci. 2019, 227, 37-43. [CrossRef]

33. Alvarez, M.A.; Moreno-Arribas, M.V. The problem of biogenic amines in fermented food the use of potential biogenic aminedegrading microorganisms as a solution. Trends Food Sci. Technol. 2014, 39, 146-155. [CrossRef]

34. Kelly, D.; King, T.P. Luminal Bacteria: Regulation of Gut Function and Immunity. In Gut Environment of Pigs, 1st ed.; Piva, A., Knudsen, K.E.B., Lindberg, J.E., Eds.; Nottingham University Press: Nottingham, UK, 2001; p. 113.

35. Yang, Z.; Liao, S.F. Physiological effects of dietary amino acids on gut health and functions of swine. Front. Vet. Sci. $2019,6,169$. [CrossRef]

36. Lindberg, J.E. Fiber effects in nutrition and gut health in pigs. J. Anim. Sci. Biotechnol. 2014, 5, 15. [CrossRef]

37. Xia, L.; Yang, Y.; Wang, J.; Jing, Y.; Yang, Q. Impact of TGEV infection on the pig small intestine. Virol. J. 2018, 15, 102. [CrossRef] [PubMed]

38. Buchon, N.; Broderick, N.A.; Poidevin, M.; Pradervand, S.; Lemaitre, B. Drosophila intestinal response to bacterial infection: Activation of host defense and stem cell proliferation. Cell Host Microbe. 2009, 5, 200-211. [CrossRef] [PubMed] 